\title{
Packaging and Brand Label Training in Karak Home Industry, Kalijirak
}

\author{
Fadjar Harimurti ${ }^{1}$, Bambang Widarno ${ }^{2}$ \\ 1.2. Faculty of Economy, Universitas Slamet Riyadi \\ Surakarta, Indonesia \\ fadjarharimurti@gmail.com
}

\begin{abstract}
Community Service Activities were carried out in Talang Kalijirak Village, Tasikmadu Karanganyar. In the village, there is a home industry that produces Karak. Sriwahyuni, a person with a disability, is one of the perpetrators of the home industry. Karak's production business aims to increase income. Based on the observations, the problems faced by partners in marketing their products are: (1) poor product packaging; (2) no product brand/label; (3) less effective marketing system. The solutions to this problem are: (1) assisting partners in the packaging process; (2) assist in the creation of visually appealing labels (3) assisting partner in promotion by displaying banners. The expected result of all PKM activities is an increase in the number of customers from Partners. Community Service Activities are proven to have provided benefits for Partners. For example, improving product packaging with plastic materials that are stronger and more hygienic, products already have the YU-SI Brand, and on product labels, the composition of ingredients and call orders are listed. In the future, these products are expected to compete in the market and increase sales.
\end{abstract}

Keywords- Home industry, Packaging, Label, Promotion.

\section{INTRODUCTION}

Product attributes are one of the important things in consumer purchasing decisions. Product attributes for snacks such as packaging and brand are simple examples that also affect the value and image of the product. In reality, the product packaging produced by Home Industry has not been considered, and some even do not have a brand. Packagings, brands, and labels are vital concerns for marketers to develop, to compete and to support the sales.

Kotler (2012) states, a product is anything that can be offered to satisfy a need or want. Simamora (2014) defines product attributes as factors that consumers consider when purchasing a brand or product category attached to the product or becomes part of the product itself. Product attributes mentioned refer to brand, quality, packaging, label. completeness of feature, design, and after-sales service.

Promotion is a significant marketing activity that can be used as a strategy to communicate products to consumers. The use of promotional media can benefit companies in introducing and marketing their products and maintain relationships between companies and consumers (Njoto \& Sienatra, 2018). To increase sales, it is necessary to have suitable promotional activities, which can be done through sales promotion, advertising, and personal selling (Tjiptono, 2016).
Packaging and Brand Labeling Training at the Karak Home Industry in Kalijirak is a form of concern from the UNISRI Service Team, which is motivated by the many home industries that have not paid attention to the importance of developing product attributes on the packaging, branding, labeling and the use of promotional media. This Community Service Activity was compiled based on the guidelines applicable at UNISRI Surakarta. Community Service is held in Talang Kalijirak Village, Tasikmadu Karanganyar. The majority of the villagers' livelihood is cultivating rice. Whole grains of rice are sold from the rice harvest, while the crushed rice is usually called groats, processed into traditional crackers, namely Karak Nasi.

Numerous home industries create rice Karak, one of which is run by Mbak Sri Wahyuni, a disabled woman. Mbak Sri Wahyuni is aided in her business operations by two additional family members. The home industry has only been operating for one year and is used to supplement revenue. The firm is considered as prospective because people purchase Karak on a daily basis. In general, raw materials are readily available. It is simply that because this industry is still small and raw resources are scarce, they continue to create Karak in the old manner. The production site does not accurately depict a hygienic production site, and so need improvement. The production machinery is still still rudimentary, utilizing a wood furnace, as is the printing equipment for Karak. Karak production starts from the process of cooking the groats into porridge.

Figure 1. Karak Processing

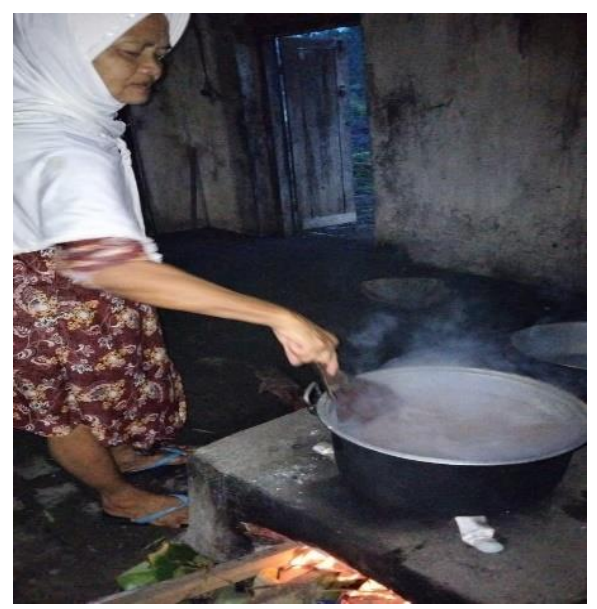

Source: Karak Home Industry in Kalijirak, 2021 
Rice groats are cooked on a wood stove, after the groats are cold, then they are molded into Karak

Figure 2. Karak porridge formed

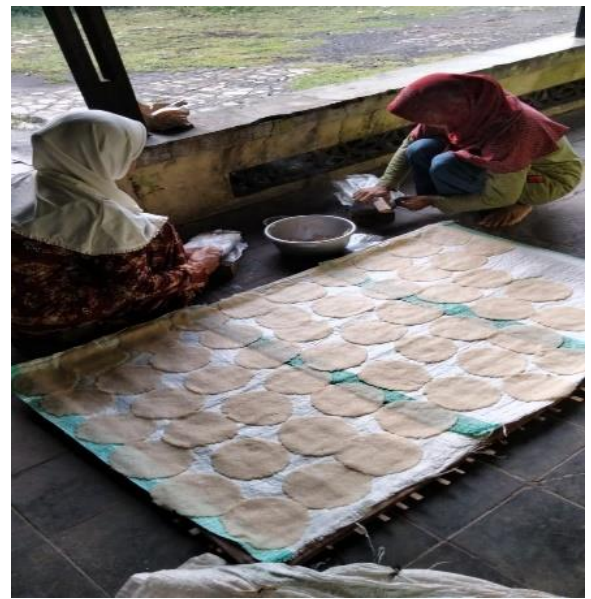

Source: Karak Home Industry in Kalijirak, 2021

Following that, the Karak plates are dried in the sun, relying on sulight.

Figure 3. The process of drying Karak

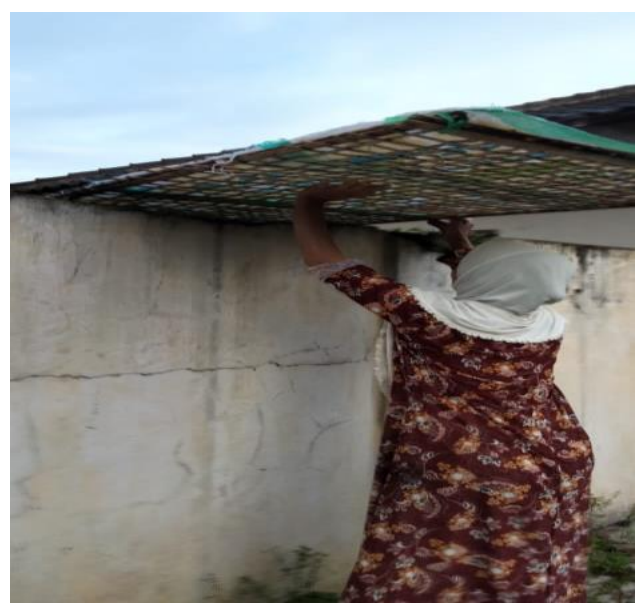

Source: Karak Home Industry in Kalijirak, 2021

Concerning product marketing, Sri Wahyuni's home industry still needs guidance because her product sales are still in the conventional way where the product is packaged in ordinary clear plastic packaging without product identity or labels.

Figure 4. Dried Karak packed in a plastic bag without label

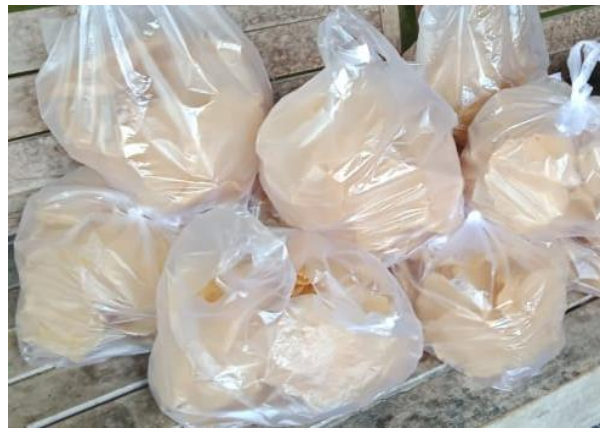

Source: Karak Home Industry in Kalijirak, 2021
The following table summarizes the working circumstances of partners at Sri Wahyuni's Home Industry in Talang Kalijirak village, Tasikmadu Karanganyar.

Table 1

Partner Condition

\begin{tabular}{lll}
\hline No. & DESCRIPTION & $\begin{array}{l}\text { SRI WAHYUNI } \\
\text { INDUSTRY } \\
\text { HOME }\end{array}$ \\
\hline $\mathbf{1}$ & Name of the owner & Sri Wahyuni \\
\hline $\mathbf{2}$ & Address & $\begin{array}{l}\text { Talang Kalijirak } \\
\text { Tasikmadu } \\
\text { Karanganyar }\end{array}$ \\
& & 2019 \\
\hline $\mathbf{3}$ & Since & 10 Kg/day \\
\hline $\mathbf{4}$ & Production capacity & Taken right away \\
\hline $\mathbf{5}$ & Marketing & Karanganyar and \\
& & its surroundings \\
\hline $\mathbf{7}$ & Types of products & Rice Karak \\
\hline $\mathbf{8}$ & Price & RP. 15.000/Kg \\
\hline $\mathbf{9}$ & Raw material & Rice groats \\
\hline $\mathbf{1 0}$ & Auxiliary Material & Seasonings \\
\hline $\mathbf{1 1}$ & Employee & 2 people \\
\hline $\mathbf{1 2}$ & Human Resources: & \\
\cline { 2 - 3 } & -Owner & -Special-Needs \\
& & Education \\
\cline { 2 - 3 } & -employee & -Junior \\
\hline
\end{tabular}

Some of the Partner problems identified include aspects of production, facilities, product marketing, and business management, which are presented in the following table.

Table 2

Partner Problem Identification

\begin{tabular}{lrl}
\hline No. & ASPECT & PROBLEM \\
\hline $\mathbf{1}$ & Production & $\begin{array}{l}\text { a. The layout of the production } \\
\text { site is inadequate, }\end{array}$ \\
& $\begin{array}{l}\text { b. Production equipment is less } \\
\text { hygienic. }\end{array}$ \\
& $\begin{array}{l}\text { c. Home Industry productivity } \\
\text { is not yet optimal because the } \\
\text { equipment used is still limited. }\end{array}$ \\
\hline $\mathbf{2}$ & Facility & $\begin{array}{l}\text { a. There are no significant } \\
\text { problems with water and fuel in } \\
\text { the form of wood. }\end{array}$
\end{tabular}

b. The storage area for raw materials is adequate, which is stored in barrels. 


\begin{tabular}{ll}
\hline & $\begin{array}{l}\text { c. The storage place for the } \\
\text { finished product is in the form of } \\
\text { an unfavorable Karak that makes } \\
\text { the Karak crumble. }\end{array}$ \\
\hline $3 \quad$ Marketing & $\begin{array}{l}\text { a. The product is packaged in } \\
\text { ordinary and thin clear plastic so } \\
\text { that it is less attractive and less } \\
\text { safe for Karak (breaks easily) }\end{array}$ \\
& $\begin{array}{l}\text { b. It doesn't have a brand and } \\
\text { label yet so it's not known to } \\
\text { many consumers }\end{array}$ \\
& $\begin{array}{l}\text { c. The marketing system is also } \\
\text { less active, although so far the } \\
\text { products produced are } \\
\text { acceptable to consumers }\end{array}$ \\
\hline $\mathbf{4}$ Management & $\begin{array}{l}\text { a. Not familiar with } \\
\text { entrepreneurial management, } \\
\text { production management, } \\
\text { financial management and } \\
\text { accounting. }\end{array}$ \\
\hline
\end{tabular}

After identifying several issues with partners, the UNISRI PKM Team has decided to focus exclusively on the marketing aspect for the Community Service year 2020/2021. The promised outputs are mandatory in the form of articles published in accredited journals and optional in the form of mass media and brand publications.

\section{FINDINGS AND DISCUSSION}

This community service activity took a location in Talang Kalijirak Village, Tasikmadu Karanganyar, Tasikmadu District, Karanganyar Regency. The target of the activity is Mbak Sriwahyuni's home industry in Talang Kalijirak Village, Tasikmadu District, Karanganyar Regency. The form of community service activities is carried out by providing training on applying marketing strategies for Karak food products (Rice Crackers) through packaging improvements and branding.

This community service activity will be carried out through three stages, namely the details of the activities as follows:

Table 3

Implementation Timeline

\begin{tabular}{lll}
\hline No. & Type of activity & Time \\
\hline $\mathbf{1}$ & Field observation & Dec-20 \\
\hline $\mathbf{2}$ & Activity Implementation & 5-Mar-21 \\
\hline $\mathbf{3}$ & Preparation of reports & Nov-21 \\
\hline
\end{tabular}

This community service is carried out by providing training on marketing strategies for managing Karak food products in Mbak Sriwahyuni's ancestral village of Talang Kalijirak, Tasikmadu District, Karanganyar Regency. The material used to conduct activities is based on marketing management theory and the development of marketing strategies, particularly in the areas of packaging, brands, labels, and promotional media. On March 5, 2021, service activities were conducted in collaboration with the UNISRI Surakarta Faculty of Economics Service Team.

The following stages are used to adjust the implementation of Service Activities to the previously prepared schedule:

\section{Preparation and Debriefing Stage}

The preparatory stage is an observation activity that focuses on analyzing the actual issue and identifying shared perceptions. The stages of service activities began with field observations on Saturday, December 2, 2020, from 9:00 a.m. to 12:00 a.m. WIB, after obtaining permission from Mr. Tri Joko SH, the Head of Kalijirak Village. According to observations, Partners face the following difficulties and constraints karak products are packaged in plain, thin clear plastic to make them less appealing and therefore less safe for Karak (breaks easily).

Karak products do not yet have a brand/brand and label, and thus are unfamiliar to a large number of consumers. Although the marketing system is less active, consumers have accepted the products produced thus far. Based on the analysis of the problem, the Service Team prepares training materials and arranges an implementation schedule.

\section{Implementation Stage}

a. Session I held on Saturday, March 5, 2021, from 9:00 a.m. to 11:00 a.m. WIB.

The Service Team explains the product marketing concepts and strategies. Regarding the problem to be solved, Partners are given the following explanation:

1) The importance of developing packaging, branding, labeling, and promotional activities as a sales strategy.

2) Partners are informed on the meaning and function of packaging, as well as the materials and equipment used to package products. Additionally, partners are shown examples of effective and attractive product packaging.

3) Partners are educated about the brand's meaning and function. Partners are presented with examples of visually appealing product brands.

4) Partners are educated on the meaning and purpose of labeling. Partners are shown examples of comprehensive and visually appealing product labels.

5) Partners are trained about promotional media and their purposes. Partners are shown examples of visually appealing promotional materials. 
The Service Team conducted an assessment by inquiring about the material delivered. By the end of Session I, Partners have a general understanding of and ability to differentiate between the following: (1) Packaging is the outermost part used to wrap the product; and (2) Brand is the writing, logo, or symbol used to represent an individual/identity. company's (3) A label is a brief description of the packaging of a product. (4) Promotion is an activity that informs the market/consumer about the product.

b.Session II, held on Saturday 5 March 2021, 11.00 to 13.00

In Session II, the Service Team presented explanations and Guided Exercises on how to improve product packaging, incorporate brands and labels, and use MMT as a promotional medium.

Prior to the training, the Service Team assists Partners in bringing prepared media, particularly:

(1) Packaging enhancement materials in the form of thicker, more hygienic OPPO thick plastic packaging and plastic press tools (Impluse Sealer),

Figure 5 Packaging Improvements with OPP thick plastic material

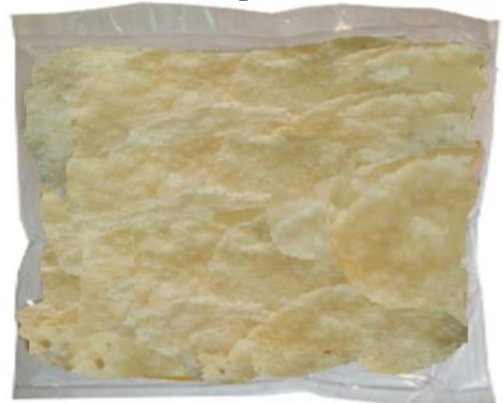

Source: Karak Home Industry in Kalijirak, 2021

The YU-SI Brand on the sticker is an abbreviation for the name Mbakyu Sri. Along with the brand name, the sticker includes information about the ingredients' composition and contact information for consumers to easily order products. Apart from serving as a business identity, the YU-SI brand is expected to increase Karak's consumer and public awareness. According to consumer perceptions, the existence of the Karak YU-SI brand may also contribute to the development of a positive product image.

Partners are extremely enthusiastic about participating in the Training and have gained a solid understanding of the importance of packaging, brands, labels, and promotional media during its implementation. The results of the Training have provided benefits for Partners, namely (1) Karak Beras products have better packaging with more robust and hygienic plastic materials (2) the product has the YU-SI brand (3) on the label includes the ingredient composition and number HP to make it easier for consumers to order products. (4) Making MMT a promotional medium is expected to increase sales. In the future, Mitra's products are expected to compete in the market and earn better profits.

\section{Evaluation Stage}

The service activities that have been carried out can be said to run smoothly according to a predetermined schedule, but it is realized that in its implementation, the successful marketing of YU-SI brand Karak products requires good processes and management from Partners. The service team hopes that this service program will help a lot with marketing problems faced by Partners. In the future, the Home Industry of Karak YU-SI products produced by Partners is expected to grow and compete in the market to increase sales and profits.

\section{CONCLUSION}

Community service activities in the form of training have benefited Partners by assisting in the enhancement of the attributes of Karak Kalijirak products, particularly in this case related to product packaging, branding, and promotional media. Product attribute development is a strategy for increasing product value and generating consumer interest in order for the Karak Kalijirak Tasikmadu Karanganyar Home Industry to grow and generate higher profits in the future.

\section{REFERENCES}

[1] Kotler, P. (2012). Manajemen Pemasaran, Analisis, Perencanaan, Implementasi dan Kontrol. Jakarta: Prehalindo.

[2] Njoto, D. P. \& Sienatra, K. B. (2018). Pengaruh Promosi Terhadap Keputusan Pembelian Konsumen Wenak Tok. Performa Jurnal Manajemen dan Start-Up Bisnis, 3(5), 612-618.

[3] Simamora, B. (2014). Panduan Riset Perilaku Konsumen. Jakarta: Gramedia Pustaka Utama.

[4] Tjiptono, F. (2016). Strategi Pemasaran, Yogyakarta: Andi Offset. 